\title{
SUPERVISÃO DE ENSINO: LEGISLAÇÃO E ATUAÇÃO NAS DÉCADAS DE 1960 A 2000
}

\author{
Ester Chichaveke ${ }^{1}$ \\ Marcos Francisco Martins ${ }^{2}$
}

\begin{abstract}
RESUMO
Este artigo relata os resultados de uma pesquisa documental que analisou as legislações estaduais e federais que orientaram a prática da inspeção/supervisão de ensino no período de 1960 a 2000 e também os registros das visitas desses profissionais às unidades escolares da Diretoria de Ensino - Região de Itapetininga/SP. Foi feito o cotejamento entre essas fontes da pesquisa, com a finalidade de verificar em que medida o exercício profissional da supervisão ocorreu de acordo com o prescrito. A conclusão é a de que as regulamentações legais balizaram, decididamente, o perfil e a atuação dos inspetores/supervisores, marcados por um tipo de fazer mais administrativo, burocrático e técnico do que pedagógico.

Palavras-chave: Supervisão de Ensino; inspetor de ensino; Diretoria de Ensino de Itapetininga.
\end{abstract}

\section{EDUCATIONAL SUPERVISION: LAW AND PRACTICE IN DECADES OF 1960 TO 2000}

\begin{abstract}
This article reports the results of desk research that analyzed the state and federal laws that guide the practice of inspection and supervision of education from 1960 to 2000 and also the records of the visits of these professionals to the school units of the Educational Board Region Itapetininga / SP. It was made the comparison between these sources of research, in order to verify to what extent the professional practice of supervision occurred as prescribed. The conclusion is that legal regulations as guidelines, decidedly, the profile and the performance of the inspectors/supervisors, marked by a kind of do administrative, bureaucratic and technical and not pedagogical.
\end{abstract}

Keywords: Supervision of Education; school inspector; Itapetininga Educational Board.

\section{Introdução}

Este artigo resulta de uma pesquisa realizada entre 2013 e 2015 , na qual se analisou as normas legais que circunscreveram a inspeção/supervisão de ensino e as transformações ocorridas no interior dessa função. Tomou-se como objeto algumas das principais legislações que afetaram essa atividade profissional nas quatro últimas décadas do século XX, nos âmbitos federal e estadual de São Paulo, bem como os Termos de Visita da Supervisão de Ensino (TV) da Região de Itapetininga, entre os anos de 1960 a 2000, que foram àquelas colacionados. Ao todo foram pesquisados $736 \mathrm{TV}$ em seis livros do período e do local que delimitaram a pesquisa. 
Entende-se como Termos de Visita um gênero de texto similar a relatórios administrativos, circuláveis na esfera oficial pública. São constituídos por estrutura de relativa uniformidade e lavrados pelos Supervisores de Ensino em Livros próprios arquivados nas Unidades Escolares por ocasião das periódicas visitas. Objetivam, prioritariamente, consignar as orientações/determinações desses profissionais aos agentes escolares, além de comprovar o efetivo exercício, externo à Delegacia/Diretoria de Ensino. Será utilizada, na maioria das vezes, a expressão inspetor/supervisor e/ou inspeção/supervisão, considerando que as duas nomenclaturas estão inseridas na periodicidade da pesquisa.

Na primeira parte do texto são apresentadas análises sobre as legislações vigentes no período circunscrito pela pesquisa, com destaque para as Leis 4024/61 e 5540/68. No tópico subsequente, a 5692/71 torna-se objeto de investigação, sendo seguido pela atual LDB: 9394/96. Esses legislações de âmbito federal são listadas juto com as de âmbito estadual de São Paulo, as quais orientaram a atuação da inspeção/supervisão nas quatro últimas décadas do século XX, e subsequentemente tem-se um Quadro em que as ações/atividades coletadas nos Termos de Visita são descritas e correlacionadas às atribuições da supervisão pedagógica arroladas no Decreto 7510/1976. O que se percebe-se, em síntese, da análise do período avaliado, com o cotejamento entre legislação e TV, é que na trajetória desse profissional, cujas nomenclaturas se alternaram ("técnico", "inspetor", "supervisor pedagógico"), esteve em relevo um tipo de prática cuja ênfase se dá na mensuração da eficiência dos resultados educacionais, aferidos por meio do poder de um controle especializado e institucionalizado, algo distante da dimensão propriamente educativa do fazer desse profissional.

Com essa temática e característica textual, os leitores são convidados à leitura deste artigo porque poderão não apenas conhecer um quadro sintético das normativas legais que orientaram a inspeção/supervisão de ensino, mas também as transformações ocorridas nessa função educativa que, sobremaneira, impacta a educação escolar.

\section{Análise da legislação sobre a Supervisão de Ensino: 1960 a 2000}

Ao perpassar a profissionalidade do Supervisor de Ensino, constata-se que desde o Ratio Studiorum estava presente a ideia de supervisão educacional (SAVIANI, 2008). Em 1931, Francisco Campos criou o Serviço de Inspeção, correlato ao cargo de "Inspetor Escolar". Na rede pública paulista, com a LC (Lei Complementar) 114/1974, a denominação é alterada para "Supervisor Pedagógico", subsistindo-se até a promulgação da LC 201/78; a partir daí o cargo passou a ser nomeado "Supervisor de Ensino", o qual perdura até hoje.

$\mathrm{O}$ início do século XX acolheu transformações que foram sentidas especialmente após a 1. a Guerra Mundial (1914-1918), assinaladas pelo crescente processo de industrialização, urbanização e internacionalização do Brasil. Esses processos repercutiram no ideário educacional, que precisou ser adaptado para educar as massas com o adestramento para o trabalho. Desse cenário emanava-se um ambiente propício às reformas educacionais e o nascimento da Associação Brasileira de Educação - ABE -, fundada por Heitor Lira, foi um desses intentos. Criada em 1924, fortaleceu o debate sobre as questões educacionais entre os próprios educadores, deslocando a discussão realizada pela elite econômica e líderes políticos. Concomitantemente a ela, dá-se o "[...] surgimento dos profissionais da educação, isto é, o aparecimento dos técnicos em escolarização, constituindo-se como uma nova categoria profissional" (SAVIANI, 2008, p. 25). 
Em 1931, Francisco Campos, Ministro da Educação, pelo art. 51 do Decreto ${ }^{\circ}$ 19.890, de 18/04, criou o Serviço de Inspeção direcionado aos estabelecimentos de ensino secundário. Cabia aos inspetores aplicar exames, fiscalizar e monitorar as atividades desenvolvidas nas unidades escolares. A fiscalização e o controle exercidos por esses profissionais no interior do sistema educativo eram sistemáticos e rigorosos, sobretudo, na observância e cumprimento da legislação vigente.

Em 1932 vem à tona o "Manifesto dos Pioneiros da Educação Nova", documento balizado no ideário chamado escolanovismo, cujo objetivo era o de superar a escola tradicional, com a proposição de uma educação interativa e autônoma, adequada às transformações culturais, econômicas e sociais, aproximando educação, desenvolvimento e progresso. "Era a tese escolanovista de uma escola renovada, com intuito profissionalizante, regionalizada" (GHIRALDELLI, 1994, p. 42). Assim, a contribuição científica ocupava posição sobreposta frente às demandas educacionais, daí a necessidade de profissionais capazes de lidar com ela. Neste contexto "[...] ganham relevância os técnicos, também chamados de especialistas em educação, entre eles o supervisor" (SAVIANI, 2008, p. 27).

Neste recorte temporal pesquisado, observa-se que a função inspetora/supervisora é perpassada pelos dispositivos legais que a constituíram. Entre as principais normas federais e estaduais que orientaram a atuação da inspeção/supervisão nesse período estão as seguintes:

* Âmbito federal:

- 1960:

. Lei $n^{\circ}$ 4.024/61: lei de diretrizes e bases da educação nacional (LDB);

. Lei $n^{\circ} 5540 / 68$ : fixa normas de organização e funcionamento do ensino superior e sua articulação com a escola média;

. Parecer no 252/69 e Resolução do Conselho Federal de Educação 2/69: fixam os $-1970^{3}$ : conteúdos mínimos e duração do curso de Pedagogia;

. Lei $5692 / 71$ : fixa diretrizes e bases para o ensino de $1^{\circ}$ e $2^{\circ}$ graus;

$-1980^{4}$ :

. Constituição da República Federativa do Brasil de 1988;

- 1990:

. Lei n ${ }^{\circ}$ 9394/96 (LDBEN): estabelece as diretrizes e bases da educação nacional;

- 2000: sem legislação a ser citada

* Âmbito estadual:

- 1960: sem legislação a ser citada

- 1970:

. Lei Complementar (LC) no 114/74 - Estatuto do Magistério Paulista;

. Decretos $n^{\circ}$ 5.586/75 e $n^{\circ} 7.510 / 76$ : reorganização da Secretaria de Estado da

Educação de São Paulo (SEESP); fixação de atribuições para o Supervisor Pedagógico;

. LC no 201/78: Estatuto do Magistério Paulista (alteração da denominação para Supervisor de Ensino).

- 1980:

- Decreto $n^{\circ}$ 17.329/81: define a estrutura e as atribuições de órgãos e as competências das autoridades da SEESP;

-1990 :

LC no 444/85: reestruturação do Estatuto do Magistério Paulista;

. LC $n^{\circ}$ 744/93: institui vantagens pecuniárias para os integrantes da classe de Supervisor de Ensino, do Quadro do Magistério (Q.M.) e determina as competências;

. Decreto $n^{\circ} 39.902 / 95$ : reorganiza os órgãos regionais da SEESP; 


\author{
. LC n $n^{\circ} 836 / 97$ - institui plano de carreira, vencimentos e salários para os integrantes \\ do Q.M. da Secretaria da Educação. \\ - 2000:
}

. Resolução da $\mathrm{SE} n^{\circ}$ 53/2000: dispõe sobre procedimentos relativos à administração e ao controle de estoque do Sistema Centralizado de Merenda Escolar;

As normas legais de âmbito estatal a seguir elencadas não foram apontadas acima porque excederem a periodicidade temporal da pesquisa:

* Comunicado da SEE de 30/07/2002: estabelece o perfil do Supervisor de Ensino;

* Resolução ${ }^{\circ}$ 70/2010: dispõe sobre os perfis profissionais, competências e habilidades requeridos dos educadores da rede pública estadual e os referenciais bibliográficos que fundamentam os exames, concursos e processos seletivos, e dá providências correlatas.

Abarcando o período posterior ao da Segunda Grande Guerra, essas legislações expressam a intensificação do debates sobre à reconstrução dos processos educacionais, que desembocaram na primeira Lei de Diretrizes e Bases da Educação Nacional, de 20/12/1961. Durante a década de 1960 e início da de 1970, a educação brasileira passou por significativas reformas, sob a égide da ditadura, que durou mais de vinte anos. Neste período as reformas implicaram adequações executadas de forma verticalizada, sem a presença dos principais sujeitos envolvidos nesse processo.

Esse contexto pautava a contenção do populismo $^{6}$ e a captação de investimentos estrangeiros, objetivando ao fortalecimento do setor empresarial. Dessa forma, as multinacionais dominaram grande parte da economia no território nacional, o que, "[...] no período pós-guerra, cristaliza-se a supremacia econômica dos EUA. Não tarda, então, a invasão americana" (ARANHA, 1996, p. 195). As repercussões do regime ditatorial foram sentidas na educação "[...] pela repressão, privatização de ensino, exclusão de boa parcela das classes populares do ensino elementar de boa qualidade, institucionalização do ensino profissionalizante, tecnicismo pedagógico e desmobilização do magistério através de abundante e confusa legislação educacional (GHIRALDELLI, 1994, p. 163). Os doze Acordos MEC-USAID (Ministério da Educação e Cultura e United States Agency for International Development) tinham objetivo de adotar medidas para ajustar o sistema de ensino ao desenvolvimento da economia capitalista, estreitando relações entre escola e mercado de trabalho, formando o cidadão por disciplinas como Educação Moral e Cívica, Organização Social e Política do Brasil e Estudos de Problemas Brasileiros e aproximandose da comunidade, por meio de conselhos de empresários e mestres (ARANHA, 1996, p. 213).

A subserviência dos referidos pactos resultaram nas diretrizes reformistas culminadas nas leis federais 4024/1961, 5.540/68 e 5.692/71. Na primeira LDB, promulgada em 1961, são estabelecidas, entre outras, as diretrizes para criar e implantar o Ministério da Educação, as Secretarias Estaduais de Educação e os órgãos federativos e estaduais adjacentes. À instância federal cabia a determinação de metas educacionais de abrangência nacional, donde resultam ações como a formação de agentes educacionais por meio do Curso Normal, de nível médio e voltado ao ensino primário, entre eles os supervisores, conforme o art. 52 da LDB 4.024/61 (BRASIL, 1961).

A Lei 5.540, de 1968, intitulada como Reforma Universitária, dispunha sobre os mecanismos de reestruturação do ensino superior e sua articulação com a escola média. É nela que o "supervisor escolar" se apresenta oficializado face aos demais agentes educacionais: "[...] é quando se quer emprestar à figura do inspetor um papel 
predominantemente de orientação pedagógica e de estímulo à competência técnica, em lugar da fiscalização para detectar falhas e aplicar punições, que esse profissional passa a ser chamado de supervisor" (SAVIANI, 2008, p. 26-27). É este o caso do Estado de São Paulo, "[...] onde reserva o nome de supervisor ao agente educativo que desempenha as funções antes atribuídas ao inspetor" (Idem, p. 26-27). Assim, o sistema educacional passou a contar com os especialistas da educação, definindo que o curso de Pedagogia passaria a oferecer especializações em educação, dentre as quais a de supervisão escolar, conforme se constata em seu art. 30 da lei supracitada: “[...] A formação [...], bem como o preparo de especialistas destinados ao trabalho de [...] supervisão, inspeção no âmbito de escolas e sistemas escolares, far-se-á em nível superior" (BRASIL, 1968).

$\mathrm{O}$ curso de Pedagogia passou a formar especialistas em educação para exercer funções de "supervisão", "administração", “inspeção" e "orientação". Emanaram-se as habilitações, dentre elas a de Supervisão Escolar. Nesse contexto, o supervisor assume-se como mediador junto aos órgãos centrais do sistema, tornado-se "[...] agentes para operar a máquina burocrática" (SAVIANI, 2008, p. 28).

Na década de 1970 foi publicada a Lei 5692/71, que estabeleceu reformas para o ensino de $1 .^{\circ}$ e $2 .^{\circ}$ graus, marcada pelo espírito da profissionalização. $\mathrm{O}$ ideário projetado ao serviço de supervisão nessas leis federais aponta para atribuições voltadas à coordenação, controle, fiscalização, eficiência e produtividade relacionadas à aplicação das políticas de ensino no âmbito intra e extraescolar, diretamente influenciadas pelo discurso desenvolvimentista ${ }^{7}$, do qual repercutiu a tendência pedagógica tecnicista. Nela, “[...] o elemento principal passa a ser a organização racional dos meios, ocupando professor e aluno posição secundária, relegados que são à condição de executores de um processo cuja concepção, planejamento, coordenação e controle ficam a cargo de especialistas" (SAVIANI, 1988, p. 24).

Contudo, é com a publicação do Parecer do Conselho Federal de Educação (CFE) n. ${ }^{\circ}$ 252 de 1969, incorporado à Resolução 2/69, que o referido art. 30 da Lei 5540/68 é reestruturado, determinando o currículo mínimo para o curso de Pedagogia, bem como a obrigatoriedade da formação em nível superior, via graduação em Pedagogia (cf. o art. 1. ${ }^{\circ}$ do Parecer do CFE 252/1969). Saviani afirma que com este Parecer se dá a tentativa mais radical de se profissionalizar a função do supervisor educacional, "[...] embora desde pelo menos a década de 30 a idéia de supervisão tenha se encaminhado em direção à especificação das atribuições do supervisor sinalizando a sua profissionalização, permanecia, ainda, uma certa indefinição, de modo especial em relação às funções de inspeção" (SAVIANI, 2008, p. 29). De fato, com o curso de Pedagogia, fragmentado em habilitações, os técnicos receberiam instruções tecnicistas para atuarem no controle e avaliar a produtividade do sistema educativo, abrindo "[...] claramente a perspectiva de profissionalização da supervisão educacional" (SAVIANI, 2008, p. 31) por meio de uma formação ideológica ${ }^{8}$, internalizadora de conceitos e posturas próprias do ideário ditatorial. Este Parecer incorporado à Resolução 2/69 vigeu até a segunda metade da década de 1990, com a promulgação da LDBEN 9394/96.

\section{A Lei 5692/71 e as regulamentações do Estado de São Paulo nas décadas de 1970 e 1980}

Com a reforma do ensino de $1 .^{\circ}$ e $2 .^{\circ}$ graus, promovida pela 5692/71, houve a reiteração dos determinantes da Lei 5540/68, no que tange à formação de especialistas da educação e à ratificação dos aspectos relativos à formação em curso de graduação, conforme 
o expresso no art. 33, que diz que a formação de "[...] administradores, planejadores, orientadores, inspetores, supervisores e demais especialistas de educação será feita em curso superior de graduação, com duração plena ou curta, ou de pós-graduação" (BRASIL, 1971).

Fica esclarecido que o art. 33 reafirma a supervisão como categoria especializada e técnica, promovida entre as habilitações a serem desempenhadas. A partir da década de 1970, houve uma multiplicidade de textos normativos que sustentaram a concepção e prática do mecanismo supervisivo, objetivando a implantação, efetividade e a avaliação da operacionalização desses no interior das organizações escolares. Essa dinâmica é operada com à transposição do modelo empresarial ao campo educacional. Sobre essa incorporação, Antunes (2009b) lembra que os serviços públicos, como a educação “[...] sofreram [...] um significativo processo de reestruturação, subordinando-se à máxima da mercadorização, que vem afetando fortemente os trabalhadores do setor estatal e público" (ANTUNES, 2009b, p. 56, grifos do autor). Assim, pode-se interpretar que quanto mais sobressaia o método técnico, mais a supervisão cumpria seus deveres ligado à manutenção da hegemonia em vigor.

Pautado na Lei 5692/71, o então Governador do Estado de São Paulo, Laudo Natel, instituiu o primeiro Estatuto do Magistério Público de $1 .^{\circ}$ e $2 .^{\circ}$ graus do Estado, denominado pela LC n. ${ }^{\circ} 114$, de 13/11/1974, que criou, organizou e regeu o Quadro do Magistério (QM), instituindo as carreiras e a nomenclatura "Supervisor Pedagógico como classe de Especialistas de Educação". Suas funções gerais estão explicitadas no art. 2. ${ }^{\circ}$, que determina que "[...] direta ou indiretamente vinculados à escola, planejam, orientam, dirigem, inspecionam e supervisionam o ensino" (SÃO PAULO, 1974).

As funções específicas do Supervisor Pedagógico são estabelecidas por meio do Decreto $n^{\circ} 5.586$, de 5/02/1975, que dispõe sobre as atribuiçõos dos cargos e funções do Quadro do Magistério de acordo com o art. 47 da LC 114/1974. Dessa forma, no art. 7. ${ }^{\circ}$ do referido Decreto ficam estabelecidas as atribuições do Supervisor Pedagógico, voltadas a orientar o acompanhamento, avaliação e controle das proposições curriculares na área de sua jurisdição; zelar pela integração do sistema, especialmente quanto à organização curricular; compatibilizar os projetos das áreas administrativas e técnico- pedagógicas, no âmbito inter-escolar; elaborar os instrumentos adequados para a sistematização das informações; garantir o fluxo recíproco das informações entre a unidade escolar e órgãos centrais do sistema; assistir tecnicamente aos diretores e coordenadores pedagógicos quanto à elaboração e execução do plano escolar; manter-se permanentemente em contato com as escolas, por intermédio de visitas regulares e de reuniões com os diretores e coordenadores, bem como com professores; determinar providências tendentes a corrigir eventuais falhas administrativas; participar da elaboração de programas e projetos; cumprir e fazer cumprir as disposições legais relativas à organização didática, administrativa e disciplinar das escolas, bem como as normas e diretrizes emanadas das autoridades superiores; apresentar relatório das atividades executadas, acompanhado de roteiro de inspeção (SÃO PAULO, 1975).

Em 1976, por meio do Decreto n. $^{\circ}$ 7510/76, implanta-se a reestruturação da Secretaria de Estado da Educação de São Paulo - SEESP - estabelecendo, no art. 2. ${ }^{\circ}$, que um dos seus campos funcionais seria o de atuação na "[...] na prestação de assistência técnica, supervisão e fiscalização de estabelecimentos municipais e particulares de ensino de $1^{\circ}$ e $2^{\circ}$ graus, educação pré-escolar, educação especial e ensino supletivo" (SÃO PAULO, 1976). Também são elencadas no art. 78 deste Decreto atribuições da Supervisão Pedagógica, delimitadas em duas grandes áreas, a Curricular, totalizando-se treze atribuições, e a Administrativa, com dezessete ${ }^{9}$. Verifica-se, assim, que para implantar os mecanismos dispostos na Lei de 1971 era imprescindível a figura do supervisor como elo 
direto de um esboço divisório, garantindo que as decisões e orientações, de forma piramidal, se efetivassem na célula nuclear do sistema, a unidade escolar, meta última desse esquema organogramático.

Compreende-se que as atribuições dispostas à supervisão visaram a aproximá-la de ações pontuais volvidas à vitalização e à melhoria das demandas direcionadas ao processo de ensino-aprendizagem, de forma específica, quanto às questões curriculares, quais sejam: implementação do macrocurrículo (o currículo prescrito), redefinindo os ajustamentos em níveis locais; mecanismos de acompanhamento, avaliação e controle às peculiaridades locais; análise e avaliação do desempenho profissional dos agentes escolares, proposição de medidas para a melhoria da produtividade escolar, promoção do aperfeiçoamento e atualização dos docentes. Mesmo com a delimitação de atribuições em âmbito pedagógico, infere-se que essas, em linhas gerais, são permeadas por um praticismo a serviço da lógica capitalista, explícitas pelos supramencionados vocábulos em itálico, a saber: ajustamentos, controle, desempenho, produtividade. Estes termos $\mathrm{e}$ as respectivas significações minimizam os processos peculiares e reais no âmbito da unidade escolar, onde de fato se realiza a concretude das questões de aprendizagem e de ensino.

As dezessete atribuições de ordem administrativa, predominantes em relação às pedagógicas, são de certa forma vestígios do perfil exigido da inspeção escolar, ratificando, assim, a cíclica trajetória profissional da inspeção/supervisão. Ademais, mesmo com a alteração das nomenclaturas de "técnico", "inspetor" para "supervisor pedagógico" reiterase um fazer tonalizado nos aspectos mensuráveis da eficiência dos resultados, necessários para a execução de um controle especializado, pautado em uma prática condizente ao poder institucionalizado.

Pretendia-se, com a implantação da reestruturação, traçar um Sistema de Supervisão, do qual que se buscava "[...] sensibilizar as bases para uma recepção positiva das dádivas pedagógicas vindas do alto" (BUENO, 2003, p. 34), ou seja, o supervisor caracterizava-se como "[...] tarefeiro e estafeta das instâncias superiores" (BUENO, 2003, p. 34).

Em 9 de novembro de 1978, o Governador Paulo Egydio Martins promulgou o segundo Estatuto do Magistério do Estado de São Paulo, por meio da Lei Complementar 201/78, que definiu o conjunto de cargos e funções dos docentes e especialistas de educação, dentre eles o "Supervisor de Ensino". Verifica-se que uma vez mais há a alteração da nomeação do cargo do "Supervisor Pedagógico", que a partir dessa LC passa a ser intitulado "Supervisor de Ensino", sendo esse o estabelecido até nossos dias. Dessa transmutação nominal pode-se deduzir que sua apresentação deu-se de forma proposital, vez que o foco das ações supervisivas recaiu nos procedimentos que estivessem diretamente interligados com a atividade técnica de ensinar, direcionando-o para aqueles que ofereciam o ensino e demais variáveis diretamente coligadas a essa prática. Acerca dessa modificação do nome do cargo, Arroyo (2008) nos diz que a ditadura não só expulsou educadores

[...] como fez algo muito mais pernicioso que foi desterrar do próprio campo de educação até o nome educação. Deixamos de falar em educação e falamos apenas em ensino, sistema de ensino. A palavra educação, que é muito mais rica do que ensino, ficou desterrada em nossas identidades. (ARROYO, 2008, p. 8-9)

Em outubro de 1978, ocorreu o I Encontro Nacional de Supervisores de Educação (ENSE), "[...] com a preocupação básica de promover a melhoria e expansão da Supervisão Educacional Brasileira e concorrer para a expansão de ideias associativas entre os supervisores escolares" (MEDEIROS e ROSA, 1987, p. 33). No II ENSE, realizado em 
Curitiba, no ano seguinte, Saviani foi um dos palestrantes e defendeu a tese de que a função do supervisor "[...] é uma função precipuamente política e não principalmente técnica, isto é, mesmo quando a função do supervisor se apresenta sob a roupagem da técnica ela está cumprindo, basicamente um papel político" (SAVIANI, 2008, p. 32). E justificou o posicionamento ao explicar que quanto mais a supervisão se apresenta sob a roupagem de procedimentos técnicos, tanto mais é eficaz na defesa dos interesses socialmente dominantes. "[...] Em contrapartida, se os supervisores quiserem se colocar a serviço [...] dos interesses dominados, da população, do operariado em geral, então, nesse caso, eles necessitam assumir o seu papel político de modo explícito" (SAVIANI, 2008, p. 32).

Esses encontros de supervisores balizaram uma intensa jornada nacional de discussões que propunham a ruptura com a ideia de uma supervisão autoritária, reprodutivista, acrítica e a construção de uma identidade pautada na mobilização por transformações das relações sociais. Os debates versavam acerca da especificidade da função supervisora implicados na consciência de um trabalho educativo que renunciasse ao ativismo às cegas e fosse capaz de fomentar perspectivas humanizadoras e relacionadas ao desenvolvimento intelectual da própria profissionalização (MEDEIROS e ROSA, 1987, p. 38-40).

Na década de 1980 foram criadas associações e movimentos como a Associação Nacional de Educação (ANDE) e a Associação Nacional de Pós-Graduação (ANPED), que incentivaram debates acerca da valorização e da democratização do ensino público. No Estado de São Paulo, em 1981 é publicado edital para o 1. ${ }^{\circ}$ concurso público de provas para o cargo de Supervisor de Ensino e neste mesmo ano funda-se a APASE - Associação Paulista de Supervisores de Ensino, hoje, Sindicato dos Supervisores de Ensino do Magistério Oficial no Estado de São Paulo, com a finalidade de reunir a categoria em defesa da escola pública paulista e, a partir de 1986, promover encontros anuais para refletir sobre a função social da educação escolar e dos desafios da supervisão de ensino nesse contexto. É oportuno ressaltar que o afloramento dessas entidades é característica da reação oposicionista às práticas políticas autoritárias, decorrentes dos anos de regime militar (SAVIANI, 2011, p. 402 a 404).

Em 1985, o governo de Franco Montoro apresentou a reestruturação do Estatuto do Magistério, oficializado pela LC 444/85. No art. 9. ${ }^{\circ}$ estabelece os requisitos para o provimento dos cargos das Classes de Especialistas de Educação do Quadro do Magistério, constituída por Orientador Educacional, Coordenador Pedagógico, Diretor de Escola, Supervisor de Ensino e Delegado de Ensino. Nessa década progride vigorosamente o tom de democratização política e educacional assinalado pela denúncia das desigualdades sociais. Nesse contexto é que se avolumam as discussões e críticas a um modelo de supervisão a serviço dos órgãos governamentais e a definição de um novo papel em que "[...] autoritarismo, burocratização e centralismo constituem obstáculos para existência de uma organização, funcionamento e, por conseguinte uma supervisão voltada à melhoria dos sistemas educacionais" (QUAGLIO, 2003, p. 50). Dessa forma, os debates e pressões traziam à tona alternativas para superar o fracasso da escola pública brasileira.

É nesse cenário que é promulgada a Constituição Federal em 1988. Ela trouxe em suas linhas palavras como autonomia, gestão democrática, cidadania, melhoria na qualidade de ensino. Em seu art. 206, explicita os princípios educacionais pelos quais o ensino deveria ser ministrado, além de plano de carreira e valorização do magistério.

Diante das implicações expostas na Carta Magna se postularam ciclos de reformas nos sistemas de ensino, que objetivavam apresentar parâmetros educacionais gerais para o território nacional com a elaboração do projeto da nova Lei de Diretrizes e Bases. 


\section{A LDB 9394/96 e as normatizações estaduais desse período}

A última década do século $\mathrm{XX}$ foi marcada por um tipo de desenvolvimento econômico orientado por conceitos como “[...] enxugamento da máquina pública, privatizações, terceirizações, racionalização, descentralização, autonomia, entre tantas outras, [que] sugerem novas demandas de formação dos trabalhadores, mais ágeis, flexíveis, antenados com as novas tecnologias" (FERINI, 2008, p. 28). No âmbito da educação brasileira a tônica foi determinada pela descentralização da administração dos sistemas de ensino. Nessa conjuntura, administradores e supervisores foram induzidos a assumirem-se como líderes, no sentido de controlar e fiscalizar a implantação das reformas elaboradas e planejadas pelo órgãos centrais (QUAGLIO, 2003, p. 51). Sobre essa proposição Antunes (2009a) afirma que a educação do capital é uma educação “[...] formal, parcelar, hierarquizada. Quem elabora? A gerência científica. Toda a concepção é da administração, os que pensam, elaboram; e a execução é responsabilidade dos trabalhadores. O Homo sapiens e o Homo faber" (ANTUNES, 2009a, p. 30, grifos do autor).

Pode-se, assim, afirmar o cumprimento dessas funções ao analisar as determinações estabelecidas na LC $\mathrm{n}^{\circ}$ 744/93, que em seu art. $9^{\circ}$ incluiu competências de supervisionar e fiscalizar escolas, prestando a necessária orientação técnica, providenciando a correção de falhas administrativas e pedagógicas, sob pena de responsabilidade e a realizar estudos e pesquisas, visando ao desenvolvimento do sistema de ensino (SÃO PAULO, 1993, p. 2). Observa-se que esse é mais um dos dispositivos legais que legitimou e direcionou a tradicional atuação hierarquizada da supervisão de ensino.

Embasado nesses paradigmas de inspiração empresarial é que no Estado de São Paulo o Governador Mário Covas, em 01/011995, publicou o Decreto no 39.902/95, que reorganizou os órgãos regionais, extinguindo as Divisões Regionais de Ensino com a justificativa de descentralização das ações e implantação de uma nova política educacional.

No final de 1996 foi aprovada a LDBEN após um extenso processo de discussão entre o poder legislativo e algumas instâncias educacionais. Os art. 61 a 67 da nova LDBEN dispõem sobre os profissionais da educação, estabelecendo os níveis de formação para atuação na docência e de especialistas. Especificadamente o art. 64 estabeleceu que a formação de profissionais da educação para inspeção e a supervisão deverá ser feita em cursos de graduação em Pedagogia ou em nível de Pós-Graduação (BRASIL, 1996).

A nova lei continuou a respaldar a função supervisora. Todavia, se no decorrer dos seus arts. estão premissas progressistas e inovadoras como autonomia, pluralismo de ideias e concepções, gestão democrática, liberdade de aprender, dentre outras, essas não alteraram as bases educacionais, vez que propuseram, mas não garantiram as mudanças estruturais. Manifestaram intenções discursivas, mas submetidas às ordens das políticas internacionais, por meio de agências financiadoras, como o Fundo Monetário Internacional (FMI). Esses parâmetros, inevitavelmente, determinaram a atuação dos gestores educacionais sob um "[...] ideário que busca transformar a educação num serviço mercantil" (FRIGOTTO, 2010, p. 62), pautados em formatos que estabeleceram "[...] a relação escola-empresa, associando a administração escolar às Teorias de Administração de Empresas. A reprodução, sutilmente começa a fazer parte da subjetividade da supervisão" (FERINI, 2008, p. 31).

Nessa atmosfera predominantemente economicista, o governo de Mário Covas, em 1997, instituiu o novo Plano de Carreira do Quadro do Magistério da Secretaria de Estado da Educação, por meio da LC no 836/97. Nesta se definiu, uma vez mais, a forma de provimento do cargo do Supervisor de Ensino, que a partir daí alterou-se de "Classe de Especialista de Educação", anteriormente prevista na LC 444/85, para "Classe de Suporte Pedagógico". 
A vigência desse dispositivo legal possibilita inferir que o supervisor de ensino, por pertencer à Classe de Suporte Pedagógico, aquele que, segundo sinônimos do verbete "suporte" ou do verbo suportar, deveria sustentar, apoiar ou auxiliar, neste caso, pedagogicamente, a Classe de Docentes. Daí que a ação supervisora (ao menos no texto da lei) estaria pautada na dinâmica ensino-aprendizagem, núcleo da razão de ser desses educadores. Todavia, cotidianamente, o fazer supervisor é azafamado de expedientes administrativo-burocráticos, "[...] já que o pedagógico não emerge naturalmente no exercício rotineiro da supervisão, é preciso suscitá-lo quase à força" (SILVA JÚNIOR, 1986, p. 44).

Assim sendo, observa-se no histórico da supervisão paulista um movimento cíclico, demonstrado no enredo legislativo e histórico ao longo das quatro décadas, de atribuições e práticas tecnicistas e burocráticas, bem como de concepções subservientes aos órgãos centrais, em detrimento do trabalho autônomo e propriamente educativo. Dessas constatações depreende-se que o supervisor do começo deste século é desafiado a militar contra a ordem capitalista, reificante e utilitarista, que o torna mais um técnico do que um educador.

\section{Normas legais e atuação dos supervisores nos anos 1960 a 2000: análise dos TV da Supervisão de Ensino de Itapetininga}

Nesta seção se cotejará alguns dispositivos legais e os TV das décadas de 1960 a 2000. Pretende-se confrontar os tópicos alusivos à inspeção/supervisão presentes nas normas legais com excertos registrados nos TV, para esclarecer como as normas legais aparecem (ou não) no fazer desses profissionais e se essas, de fato, legitimaram ou não determinados tipos de atividades supervisivas no recorte temporal da investigação.

Nesse movimento, são apresentadas as atribuições fixadas nos textos legislativos, a saber: LDB 4.024/1961, Programa de Assistência Brasileiro ao Ensino Elementar PABAEE (1957 a 1965), LC $n^{\circ} 114 / 1974$, Decreto $n^{\circ}$ 5.586/1975, Decreto $n^{\circ} 7.510 / 1976$, LC $n^{\circ}$ 201/1978, Decreto $n^{\circ} 17.329 / 1981$, LC no 744/1993, Decreto $n^{\circ} 39.902 / 1995$ e Resolução SE no 53/2000 e, a partir desses, as possíveis repercussões nos registros dos TV.

Nos livros de TV são analisados os registros referentes às quatro décadas da pesquisa: 1960 a 2000. Desses, foram selecionados os que ofereceram expressiva compreensão da dimensão legalista/oficial manifestada em excertos dos TV lavrados pelos inspetores/supervisores, bem como a presença ou ausência da correlação entre o disposto nas normas e as atribuições/competências desempenhadas no fazer da inspeção. Para melhor apresentação dos excertos coletados, ora eles serão exibidos em quadros comparativos, ora no corpo do texto. Para tanto, inicia-se retomando o art. 65 da LDB 4.024/1961.

$\mathrm{O}$ referido art. menciona que "[...] o inspetor de ensino [...] deve possuir conhecimentos técnicos e pedagógicos [...]" (BRASIL, 1961) para inspecionar e fiscalizar as unidades escolares distribuídas no setor geográfico a ele atribuído. Esses conhecimentos integrados pelo duo técnico-pedagógico estavam constituídos sob tecnicização dos procedimentos, sejam eles administrativos ou didático-pedagógicos, especialmente no que diz respeito à maximização do desempenho educacional, com vistas ao atendimento do ideário de expansão e universalização do ensino básico durante a década de 1960.

Nas análises dos TV verificou-se que esses conhecimentos, mormente os de ordem técnica, são traduzidos em inúmeras atividades durante a visita, como convém destacar ${ }^{10}$ : 


\begin{abstract}
Durante a visita constatei que: 1-as aulas tiveram início normalmente; 2 que a escala de férias já foi enviada; 3- que os comunicados 8/63 e 10/63 já foram atendidos; 4- que o diretor não gozou férias em janeiro; 5- que o planejamento de 63 já foi enviado. (TV de 06/05/1963)

Estão matriculados 718 alunos. Presentes hoje: 668 alunos. Porcentagem: 93,03\%. (TV de 30/10/1967)

[...] Livros de escrituração em ordem e atualizados [...] O saldo da APM [...] de Cr\$ 6.300,37 depositado na Caixa Econômica Estadual desta cidade. (TV de 07/10/1974)
\end{abstract}

Percebe-se também que os conhecimentos e as atividades voltadas particularmente à ação pedagógica (aprendizagem dos alunos e a formação didática do professor) se fazem presentes, todavia em número visivelmente inferior ${ }^{11}$ :

Em companhia do senhor diretor percorro as classes do $1 .^{\circ}$ e $2 .^{\circ}$ períodos, conversando com as senhoras professoras sôbre a marcha do trabalho escolar, palestrando com as crianças, verifico também os cadernos gráficos dos alunos, diário e semanário de lições, livros de chamada. (TV de 30/10/1967)

Com o Diretor tratei de diversos assuntos de ordem pedagógica e administrativa [...] Entrega do documento [...] sobre sugestões para as atividades de reforço [...] em Matemática. (TV de 23/08/1973)

Sob a égide da legislação que destaca e menciona os conhecimentos técnicos e pedagógicos, percebe-se que sobressaem as atividades desempenhadas no sentido de verificar se os protocolos cotidianos escolares convergem para a obtenção eficaz de resultados educacionais (livros administrativos organizados, levantamento de dados de matrículas, expedientes encaminhados da Inspetoria Regional à unidade escolar, via inspetor, e demais procedimentos escolares). É possível inferir que esses cumprimentos inspecionais (mesmo em ocasiões diminutas) visam a alcançar metas políticas e educacionais que, nesta década, perpassavam pela tentativa de erradicar o analfabetismo e a evasão escolar, por meio de programas e campanhas de alfabetização, bem como pela expansão das escolas primárias.

No início da década de 1960 são revisionados os objetivos oficiais do Programa de Assistência Brasileiro-Americano ao Ensino Elementar - PABAEE ${ }^{12}$ (instalação em 1957; foco no ensino primário), apoiado em acordos entre o Brasil e os Estados Unidos (MECUSAID) $)^{13}$, que incluíam referências voltadas à função inspetora, especialmente as associadas ao currículo (obrigações desempenhadas nas escolas, de modo a prestar inspeção precisa e pontual nas atividades docentes, conteúdos, métodos, processo avaliativo, condutas disciplinares e hierárquicas). Paiva e Paixão (1997), bem como Uczak (2010), apontam os objetivos dispostos no acordo que interferem pontualmente nas atividades dos inspetores: instituir programa de treinamento em serviço a partir de demonstração de novos métodos e técnicas para professores de escolas normais, elementares e centros regionais; elaborar materiais didáticos para escolas normais e elementares; prestar assistência no planejamento e construção de edifícios escolares e na projeção de seu respectivo aparelhamento; selecionar professores de competência profissional, eficácia no trabalho e conhecimentos da língua inglesa a fim de serem enviados aos Estados Unidos para cursos avançados no campo da educação primária (PAIVA, PAIXÃO, 1997, p. 50-51; UCZAK, 2010, p. 43).

Estes objetivos coadunaram com as demandas político-educacionais atreladas à emergente necessidade de treinamento de professores em formação nas escolas normais, 
como os que desempenhavam docência nas escolas de ensino elementar/primário. Destinavam, igualmente, à pretensão de formar multiplicadores junto às bases educacionais, em atendimento às exigências que o próprio programa estabelecia. Essas disposições estratégico-educacionais são notáveis nos registros, conforme se constata:

Visitei as obras do novo pavilhão, destinado ao Curso Primário Anexo. (TV de 20/11/1961)

Recomendei que os trabalhos de linguagem, no caderno próprio, sejam dados duas vezes por semana. Verifiquei também a maneira como estão sendo ministradas as aulas de geografia, história e ciências notando que os quadros sinóticos estão sendo seguidos conforme instrução da Delegacia. (TV de 23/04/1962, grifos nossos)

A Inspetoria Regional irá promover encontros de professores, os quais por intermédio deste formulo o convite. São os seguintes encontros em datas e locais seguintes: Ciências - em Itu - dia 1-6-64; Português - em Sorocaba - dia 3-6-64; Geografia - em Tatuí - dia 5-6-64; Matemática - em Itapetininga - dia 8-6-64; História - em Itapeva - dia 10-6-64. (TV de 19/05/1964)

[...] Recomendações: [...] 5- Levar ao conhecimento dos profs. de Português, Inglês, Matemática, Geografia e Ciências, que possuem sómente autorização federal para lecionar que há necessidade de frequentar o Curso do Cades ${ }^{14}$, de acordo com a circular 12 da I.R. de Itapetininga. (TV de 28/11/1964)

Neste primeiro período analisado (1960 a 1974), verifica-se que os dispositivos legais - LDB 4.024/1961 e o PABAEE (1957 a 1965) - e os interesses político-econômicos influenciaram a atuação dos inspetores. Isso porque que os TV demonstram seguimento ordeiro e fiel das demandas expostas na legislação em vigência naquele momento. Todavia, a leitura dos mesmos demonstra o predomínio de expedientes e procedimentos voltados à tecnocracia, em detrimento da assistência direta a docentes e discentes. Observa-se, ainda, o tom eivado de racionalidade, disciplina e "neutralidade" política.

A LC n ${ }^{\circ} 114$ de 13/11/1974, regulamentada pelo Decreto n ${ }^{\circ} 5.586$, de 05/021975, provocou alterações na função inspetora/supervisora, primeiramente em relação à denominação do cargo: de inspetor escolar para supervisor pedagógico (art. 9. ${ }^{\circ}$ da LC 114/1974), e, concomitantemente, ao catálogo de atribuições/competências (art. $7 .^{\circ}$ do decreto 5586/1975 - cf. a segunda parte deste artigo). Panoramicamente, nesse Decreto enfatizavam-se as atividades voltadas à avaliação e ao controle do currículo, sistematização e fluxo das informações entre órgãos centrais e unidades escolares, assistência técnica e treinamentos aos agentes escolares (especialmente àqueles responsáveis pelo desenvolvimento do currículo), correção de falhas administrativas, como também aquele que cumpre e faz cumprir as disposições legais e normativas emanadas das autoridades superiores. As referidas atribuições são verticalmente impostas, visando ao alcance das metas pretendidas. Verifica-se algumas dessas premissas nos próximos excertos ${ }^{15}$ :

Visei os livros de ponto, tendo carminado ${ }^{16}$ o ponto da professora A. (TV de 10/12/1975)

Em atenção as recomendações anteriores, quanto ao uso de uniforme dos Srs Professores de educação física, transcrevo o art. $11 .^{\circ}$ da Portaria n. ${ }^{\circ} 37$, de 27/6/1956 da Divisão de Educação Física - Ministério da Educação e Cultura e publicada no Diário Oficial do Estado em 6/7/1956 - Pag.57.

Art. 11. - Do Uniforme - 
Os professores de Educação Física, no desempenho das suas funções, deverão usar o seguinte uniforme:

- Sexo Masculino - a.) Calça azul marinho, com faixa branca, apropriada, ou calção preto; b.) Camisa branca com meia manga e gola olímpica ou camiseta de regatas;

c.) Sapato de tênis branco ou maratona; d.) Meia soquete branca.

- Sexo Feminino- a.) calção (bombacha) preto e saia azul marinho comprida ou calça azul marinho comprida; b.) Blusa branca, sem manga ou em meia manga, gola esporte; c.) Sapato de tênis branco; d.) Meia soquete branca. (TV de 03/11/1975)

A finalidade desta visita foi colher dados para informação no oficio do $\mathrm{Sr}$ Diretor da IV - DRE de Sorocaba no tocante as causas de evasão e reprova de alunos de 1. ${ }^{a}$ série, do ano de 1974. Após verificações feitas foi o processo reformado e remetido à Delegacia de Ensino Básico. Reina absoluta ordem, asseio e disciplina no estabelecimento. (TV de 23/04/1975)

Neste $10^{\circ}$ de Maio, dia do Trabalho, data nacional, assisti, neste estabelecimento [...] à comemoração festiva da data. Exaltado o seu significado nas palavras do Sr. Diretor, desenvolveu-se o programa, com participação dos alunos, através de poesias e cantos, preparados pelos srs. Professores [...] acentua-se o sentimento cívico de amor à Pátria, que o trabalho honesto e honrado, o trabalho dedicado, constrói, consolida e engrandece. (TV de 01/05/1975)

Nos trechos supramencionados pode-se observar que a contradição se dá entre a denominação do cargo - supervisor pedagógico - e as respectivas atribuições. Se o supervisor tem atribuição pedagógica seria, em tese, este o fazer educacional que deveria centrar sua ocupação; todavia, ao folhar termos consoantes com a lista de atribuições a ele firmado encontra-se: fiscalização e carminagem de livro-ponto (TV de 10/12/1975), retransmissão de dispositivos legais (transcrição na íntegra do texto legal, no caso do TV de 03/11/1975), visando ao seu pleno cumprimento, fluxo de expedientes e retroinformações entre órgãos centrais e escola (TV de 23/04/1975) e correção de falhas administrativas (TV de 23/04/1975). Ademais, é oportuno mencionar a ressonância militar marcada pelo patriotismo e comemoração de datas nacionais (TV de 01/05/1975), vigilância e controle da disciplina, ordem, uniformização de atitudes e hábitos (TV de 03/11/1975 e de 23/04/1975). A marca textual de encerramento "Reina absoluta ordem, asseio e disciplina no estabelecimento" está no TV de 23/04/1975 e em outros analisados.

Aproximadamente um ano depois, é publicado o Decreto no 7510, de 29/01/1976, que reestrutura e reorganiza a Secretaria de Estado da Educação do Estado de São Paulo. Nesse são reiteradas as competências contidas no Decreto de 1975 e detalhadas mediante ramificação entre área curricular e administrativa aos Grupos de Supervisão Pedagógica, associada a um enfoque sistêmico, que abrangia um escalão hierárquico de órgãos da SEESP. No entanto, são acrescentados vocábulos como "produtividade", "racionalização dos serviços", "dados estatísticos", "desempenho pedagógico", coadunadas à inspiração técnico-produtivista que se consolidava na sociedade brasileira na década de 1970.

Essas competências serão sinalizadas nos fragmentos dos TV abaixo relacionados. Considerando totalizar trinta (30) atribuições entre área curricular (treze) e administrativa (dezessete), optou-se, neste caso, a elaborar um quadro, associando as atribuições arroladas no art. 78 e as respectivas atuações assuntadas nos TV, visando a didatizar o cotejamento a ser apresentado. 
Quadro 2: Ações coletadas dos Termos de Visita correlacionadas às atribuições do Decreto 7510/1976

\begin{tabular}{|c|c|}
\hline $\begin{array}{l}\text { Atribuições da Supervisão Pedagógica arroladas no } \\
\text { art. } 78 \text { do Decreto } 7510 / 1976\end{array}$ & $\begin{array}{l}\text { Atividades coletadas dos Termos de Visita correlacionadas às respectivas atribuições } \\
\text { (período de } 29 / 01 / 1976 \text { a } 28 / 12 / 1993^{17} \text { ) }\end{array}$ \\
\hline
\end{tabular}

\section{I - na área curricular}

a) implementar o macrocurrículo, redefinindo os ajustamentos em termos das condições locais;

Estive hoje [...] no sentido de atuar na Monitoria do Projeto Ipê/86' - Módulo I - 'Quem quiser que conte outra' programa: 'A Postura do Professor'. O cronograma efetuado foi o seguinte: das 9 horas até 10,20 horas - leitura em grupo com textos das professoras Heloisa Maria Cintra Torres de Carvalho e Fanny Abramovich, da Equipe da CENP $^{18}$ - Secretaria da Educação. [...] Depois serão elaboradas determinadas perguntas sobre os textos dados. [...] Das 10,30 até 11,20 horas - respostas das perguntas feitas em forma de Painel de Debates.

11,30 - meio dia - transmissão de programa de televisão, abordando o assunto discutido em sala" (TV de 09/08/1986).

b) adequar os mecanismos de acompanhamento, avaliação e controle às peculiaridades locais;

"... com o objetivo específico de dar ciência à direção da unidade escolar, dos termos de Telegrama enviado pelo Exmo Sr. Secretário da Educação à Delegacia de Itapetininga: 'Solicito determinar [a] toda área [de] jurisdição rigoroso controle [de] frequência [de] professores, considerando frequentes apenas aqueles [que] efetivamente ministrarem aulas. Sua presença [na] Escola, sem exercício docente deve ser considerada falta. [...]" (TV de 18/04/1979).

c) assegurar a retroinformação ao planejamento curricular;

"Abordamos diversos assuntos de natureza administrativa e pedagógica, [...] a utilização do questionário onde se revela o nível de adiantamento do ciclo básico, para os casos de transferência; a atribuição de classes e aulas, onde inexiste professores efetivos e servidores disponíveis, deverá ocorrer à remessa para atribuição a nível de Delegacia de Ensino" (TV de 20/09/1984).

d) aplicar instrumentos de análise para avaliar o desempenho do pessoal das escolas no que se refere aos aspectos pedagógicos;

“[...] inicialmente visitei a classe de $1{ }^{\mathrm{a}}$ série, [...] ocasião em que observamos o desenvolvimento do projeto ligado a área de Matemática. Posteriormente, embora de forma rápida, visitei a classe da Sra Prof. a A (4. .a série A) onde conheci o instrumento de avaliação de Estudos Sociais recém aplicado, achando-o conforme ao conteúdo desenvolvido. Aos alunos desenvolvi breve preleção com vistas a incentivar o desenvolvimento de hábito de estudo. Finalizando a visita, participei de reunião para professores I que lecionam no período da manhã, em que o Prof. A desenvolveu palestra, ligada a área de ciências e subordinada ao tema - Aplicação do Método Científico na Escola de 1. ${ }^{\circ}$ Grau" (TV de 15/03/1983, grifos nossos).

e) informar ou elaborar propostas de diretrizes para avaliação do processo ensino-aprendizagem nas unidades escolares;

f) sugerir medidas para a melhoria da produtividade escolar;

"Verifiquei a aprendizagem dos alunos, inclusive chamando-os à lousa, para a escrita de palavras, conforme o nível em que se encontram. Propus, quando oportuno, a realização de exercícios para fixação do aprendido, bem como exercícios caligráficos, tendo as classes já adotado o caderno respectivo" (TV de 05/06/1991).

"Com o Sr. Diretor, estudamos várias alternativas de solução objetivando a racionalização dos serviços e organização da secretaria" (TV de 13/05/1980).

g) selecionar e oferecer material de instrução aos docentes;

"Desenvolvi para os alunos do $4 .^{\circ}$ Magistério [...] técnicas relacionadas com o Ditado de frações na $3 .^{\mathrm{a}}$ série do $1 .^{\circ}$ Grau, envolvendo a 'filosofia' do Preparo, a técnica da Execução e as estratégias de Avaliação. No final [...] pedi um trabalho grupal com os alunos" (TV de 21/10/1987).

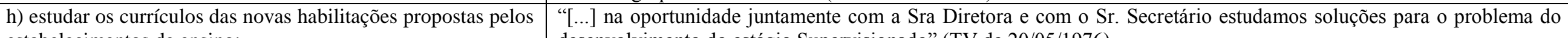
estabelecimentos de ensino;

i) acompanhar o cumprimento do currículo das habilitações desenvolvimento do estágio Supervisionado" (TV de 20/05/1976). 
existentes, bem como o desenvolvimento das atividades dos estágios;

j) diagnosticar as necessidades de aperfeiçoamento e atualização dos professores e sugerir medidas para atendê-las;

1) assegurar o fluxo de comunicações entre as atividades de supervisão e entre as de Orientação Educacional;

m) estabelecer articulação entre os serviços de currículos e os demais serviços afetos à Delegacia de Ensino;

n) assistir o Delegado de Ensino na programação global e nas tarefas de: organização escolar; atendimento da demanda; entrosagem e intercomplementariedade de recursos; recrutamento, seleção e treinamento do pessoal;

\section{II - na área administrativa}

a) supervisionar os estabelecimentos de ensino e verificar a observância dos respectivos Regimentos Escolares;

b) garantir a integração do sistema estadual de educação em seus aspectos administrativos, fazendo observar cumprimento das normas legais e das determinações dos órgãos superiores;

c) aplicar instrumentos de análise para avaliar o desempenho do pessoal das escolas no que se refere aos aspectos administrativos;

d) atuar junto aos Diretores e Secretários de Estabelecimento de Ensino no sentido de racionalizar os serviços burocráticos;

e) manter os estabelecimentos de ensino informados das diretrizes e determinações superiores e assistir os Diretores na interpretação dos textos legais;

f) acompanhar e assistir os programas de integração escolacomunidade;

g) analisar os estatutos das instituições auxiliares das escolas, verificar a sua observância e controlar a execução de seus programas;
"Tratei, com o Sr. Diretor, de diversos assuntos, em especial da Deliberação referente ao Magistério, isto é, à Habilitação Específica de 2. ${ }^{\circ}$ Grau para o Magistério [...]" (TV de 12/03/1985).

"[...] realizei, com os srs. Professores de $3 .^{a}$ e $4 .^{\text {a }}$ séries, uma reunião onde foram abordados aspectos de ordem pedagógica [...] assunto referente à composição escrita. Recomendei [...] a seqüência dos passos do preparo, execução e correção, com comentários [...] (TV de 20/08/1986).

"Estive hoje, neste estabelecimento de ensino [...] com a finalidade de realizarmos um "Encontro com Orientadores e Professores de Educação Moral e Cívica' das escolas da rede estadual de ensino, sediadas neste município" (TV de 18/10/1984).

"Dei prosseguimento a verificação das turmas de educação física, face a solicitação do Sr. Delegado de Ensino, dando por concluído o trabalho" (TV de 04/05/1983).

"A fim de participar, como aplicador, da prova de seleção de professores para o CEFAM ${ }^{19}$, estive hoje neste estabelecimento de ensino [...] Os [...] candidatos [...] foram distribuídos em duas salas e [...] a prova, que constam da elaboração de uma proposta de curso, digo, de conteúdo para a $1 .^{\mathrm{a}}$ série e dissertação como cada um pretende desenvolver o seu trabalho docente, inclusive a avaliação, devendo ainda fazer abordagens sobre a importância de sua disciplina no currículo e [...] do ensino público e como vê a formação do professor para o magistério" (TV de 21/12/1988).

"Deixei orientação complementar, relativa ao preenchimento de históricos escolares de ex-alunos do curso de $1 .^{\circ}$ Grau - Pluricurricular, com base no artigo 16 do Regimento Escolar específico para o referido curso" (TV de 06/09/1979)

“[...] Tratamos de assuntos de ordem administrativa e pedagógica de conformidade com o que determina o dec. 7.510 em seu art. 62"20 (TV de 19/01/1978).

"Ao Sr secretário deixei orientação visando a racionalização e controle do currículo e atribuição de aulas, no próximo ano letivo" (TV de 21/10/1976).

"Com o Sr Secretário estudamos soluções de ordem prática visando a adaptação da escrituração das fichas da vida escolar dos senhores alunos" (TV de 19/05/1976).

"Tratei, com o sr. Diretor de diversos aspectos administrativos de ordem oficial, inclusive fazendo considerações sobre a hierarquia das leis, para melhor entendimento das normas legais" (TV de 08/10/1985).

"[...] participei de Reunião da $\mathrm{APM}^{21}$ em que foi eleita a Diretoria para o corrente ano letivo [...] notando-se entretanto pequena afluência de sócios" (TV de 03/09/1976).

"Na sala do Orientador de Educação Moral e Cívica foram examinados o novo regimento do Centro Cívico Escolar de acordo com o modelo [...], Código de Honra do C.C.E. [Centro Cívico Escolar], livro de registros das atividades do O.E.M.C. [Orientador de Educação Moral e Cívica] e o livro de atas do C.C.E., achando-os todos conforme" (TV de $06 / 09 / 1979)$ 
h) examinar as condições físicas do ambiente escolar, dos implementos e do instrumental utilizados, tendo em vista a higiene e a segurança do trabalho escolar;

i) sugerir medidas para a revisão do prédio escolar, bem como para a renovação, reparo e aquisição do equipamento;

j) opinar quanto à redistribuição da rede física, a sua entrosagem e intercomplementariedade

1) orientar a matrícula de acordo com as instruções fixada pelo Delegado de Ensino;

m) orientar e analisar o levantamento de dados estatísticos sobre as escolas

n) constatar e analisar problemas de repetência e evasão escolares e formular soluções:

o) opinar quanto a mudança da sede do exercício, permuta, transferência e substituição do pessoal em casos não sujeitos a regulamentaç̃o própria;

p) examinar e visar documentos dos servidores e da vida escolar do aluno, bem como os livros e registros do estabelecimento de ensino;

q) sugerir medidas para o bom funcionamento das escolas sob sua supervisão;

r) opinar sobre o recrutamento, seleção e treinamento de pessoal pertencente aos estabelecimentos de ensino (SÃO PAULO, 1976).
"Com o Sr. Diretor visitamos várias dependências da escola objetivando conhecer detalhes das reformas porque passa a unidade escolar" (TV de 04/04/1979).

"Objetivo da visita: tratar de assuntos administrativos (Baixa, doação e transferências de material permanente)" (TV de 03/05/85).

“Tratamos de diversos assuntos, dentre eles a formação de Caixa de Custeio" (TV de 24/06/1993).

"Na oportunidade [...] providenciamos a montagem do expediente relacionado com a constituição da escola (Projeto de Expansão e Ocupação de rede física - 1980. Com base na orientação expedida pela Delegacia de Ensino em reunião realizada ontem, dia 03/01/80)" (TV de 04/01/1980).

“[...] tomei as providências necessárias com relação ao Anexo II e tendo em vista a Res. SE 14, de 29/1/93, verificando, classe por classe, a matrícula e as vagas do estabelecimento" (TV de 08/02/1993).

"Verificamos, também, os gráficos levantados [...] referente ao resultado das avaliações dos alunos, do $1 .^{\circ}$ bimestre. Finalmente, tomamos conhecimento do resultado das provas da Maratona Cívica, a nível de município [...] (TV de 01/06/1983).

“[...] fizemos a análise do desempenho global de alunos concluintes da 8. a série, dando andamento aos expedientes Anteriormente já havia estado nesta escola, dia 7, fazendo a análise inicial dessas situações de retenção" (TV de $12 / 01 / 1993)$.

"Juntamente com o Sr diretor estudamos a situação dos professores da escola (em exercício e afastados) com vistas ao conhecimento inicial das providências necessárias para a exata aplicação do Decreto n. ${ }^{\circ} 14.329$ de 29/11/79 e legislação complementar" (TV de 14/12/1979).

“[...] analisamos cerca de 42 (quarenta e dois) prontuários de docentes em exercício no estabelecimento, deixando com o Sr diretor os 'documentos de análise' para as providências necessárias” (TV de 12/09/1979). ${ }^{22}$

"Tratei com o Sr. Diretor [...], Assistente de Diretor e [...] Coordenadora pedagógica, de assuntos referentes a adaptação e dispensa de disciplinas, de alunos dos cursos de $2 .^{\circ}$ grau de habilitação específica para o magistério e comum. Estudamos os diversos casos existentes e orientamos quanto as soluções a serem adotadas, sendo de se registrar que as situações já estavam muito bem esquematizadas" (TV de 29/03/1985).

"Na oportunidade realizamos reunião com os funcionários da secretaria com o objetivo de orientá-los a respeito do preenchimento da ficha individual dos alunos e demais atividades relacionadas com o sistema de avaliação e promoção dos alunos" (TV de 18/11/1976).

Fonte: Elaborado pelos autores 
Em síntese, considera-se que, não obstante a alteração do nome do cargo, (focalizando, oxalá, o pedagógico) e a proposta de uma supervisão de sistema, não foi possível verificar mudanças basilares no modus operandi do supervisor pedagógico. Ressalta-se que adicionadas ao cumprimento das competências, prosseguem e permanecem os registros nos TV o posicionamento favorável dos supervisores aos momentos dedicados às comemorações cívicas e à exaltação de personagens da história brasileira. Tal postura é condizente e influenciada, reiteradamente, pelas determinações governamentais, tendo em vista que o mesmo Decreto (7510/1976) que define as competências do supervisor pedagógico institui, também, uma "Comissão Estadual de Moral e Civismo", composta por "[...] pessoas dedicadas à causa da educação moral e cívica, possuidores de ilibada probidade e notório valor cultural, observada a representação dos diferentes graus de ensino" (SÃO PAULO, 1976). Há, para tanto, um processo de internalização e fomento da consciência cívico-moral, dissimulando as contradições das relações sócio-educacionais. Para melhor estabelecer-se cotejamento entre a postura adotada pelos supervisores e os registros, convém explicitar algumas das atribuições da referida Comissão (art. 164 do Decreto 7510), voltadas a assessorar o Secretário da Educação nos assuntos pertinentes à implantação e difusão da Educação Moral e Cívica no Estado, visando à formação do caráter do brasileiro e seu preparo para o integral exercício da cidadania democrática, através do fortalecimento dos valores morais e cívicos da nacionalidade; acompanhar o desenvolvimento do ensino e da prática da Educação Moral e Cívica, tendo em vista o culto à Pátria, aos seus símbolos, tradições, instituições e aos grandes vultos de sua história; o culto da obediência à Lei, da fidelidade ao trabalho, dos princípios da fraternidade social; incentivar a criação e o desenvolvimento de Centros Cívicos; colaborar no planejamento de cursos, formação e seleção de professores para a consecução dos objetivos do ensino e da prática da Educação Moral e Cívica (SÃO PAULO, 1976).

Dentre outros pesquisados, o TV a seguir proporciona averiguar uma ação supervisiva profusa e promotora diante dos aspectos relativos à educação moral e cívica:

Na oportunidade assisti palestra do Prof. A, diretor da EEPG A como parte das comemorações da semana da Pátria, promovidas pela direção da unidade escolar e a direção do Centro Cívico Escolar [...] parabenizo a direção da escola e a Sra Orientadora de Educação Moral e Cívica pela feliz iniciativa e ao Sr A pelo brilhantismo da forma como conduziu sua palestra sob o tema 'As várias formas de Independência' (TV de 06/09/1979).

Em 9/11/1978 foi publicada a $L C n^{\circ} 201$. Uma vez mais é alterada a denominação do supervisor: de "supervisor pedagógico", passa a ser "supervisor de ensino"; contudo, essa Lei não arrola novas atribuições, sendo as mesmas do Decreto 7510/76.

Passados cinco anos, o governador Paulo Salim Maluf promulga o Decreto $\mathrm{n}^{\circ}$ 17.329, de 14/07/1981. Todavia, quanto à supervisão de ensino, são reiteradas as competências exaradas no Decreto $7510 / 76^{23}$, estipulando ínfimas alterações.

Ao analisar as atribuições delimitadas na vigência do Decreto 7510/76 (de 29/01/1976 a 28 de dezembro de 1993, quando da publicação da LC 744/1993), interessa ressaltar que há uma superabundância de atribuições vinculadas a uma complexidade de competências técnicas, funcionais e operacionais. Essas são assumidas e executadas formalmente nas escolas e escamoteadas pela literatura (neo)tecnicista. Reitera-se o fluxograma de cumprimentos ipsis litteris, pragmáticos e consensuais: da cúpula do sistema às Delegacias de Ensino, dessas à supervisão, da supervisão à escola, reafirmando-se dicotomização entre os que planejam (especialistas) e os que executam. 
Outrossim, constata-se ações pontuais, ainda que em menor frequência, na área curricular/pedagógica, visualizando registros de visita às salas de aulas e atividades voltadas à formação da equipe administrativa e docente. Entretanto, essas reduziam-se à transcrição e reprodução do idealizado pelos ditames centrais e no repasse de métodos e técnicas de ensino preestabelecidos. Todavia, a leitura analítica de cada um dos TV mostrou que a regularidade e a constância das atividades são depositadas na operacionalização de trâmites administrativos: vistoria de históricos escolares (confrontando-os com os dados dos prontuários dos respectivos alunos para aposição do "visto-confere") e de prontuários de docentes (verificação de diplomas de habilitação específica de 2. ${ }^{\circ}$ Grau para o Magistério) para, após vistoria, serem encaminhados ao MEC para fins de registro, além de verificação de fichas cadastrais, procedimentos relativos à equivalência de estudos a alunos oriundos de países estrangeiros, adaptações e aproveitamentos de estudos (pois era o supervisor a autoridade que conferia autenticidade aos documentos escolares de alunos concluintes). Convém dizer que muitos TV são concisos e, na grande maioria das visitas, se fixam na verificação de prontuários de alunos concluintes e de Livros de Ponto Docente e Administrativo.

Deste exercício exploratório verifica-se que as normas legais vigentes coadunaramse à atuação dos supervisores, na periodicidade de 29/01/1976 a 28 de dezembro de 1993. Estes as executaram no intento de garantir o ideal modernizador e racional do aparelho estatal. Desempenharam o papel de promotores da reforma sistêmica e de cumpridores da agenda técnico-produtivista nas escolas da rede estadual.

Em 1993 foi publicada a LC 744, que institui a gratificação de função para o supervisor de ensino. Nela, o governador Fleury Filho não revogou as atribuições do art. 78 do Decreto 7510/76 e nem as sucintas alterações expressas no Decreto 17.329/81. Todavia, no art. $9 .^{\circ}$ da LC 744, reitera as competências condizentes à supervisão, fiscalização e orientação técnica, providenciando a correção de falhas administrativas e pedagógicas, sob pena de responsabilidade e realização de estudos e pesquisas, visando ao desenvolvimento do sistema de ensino (SÃO PAULO, 1993, p. 2).

Verifica-se que há uma reafirmação e revalorização da ação supervisora voltada à fiscalização e a atuação técnica, como fora estabelecida desde a LDB de 1961. Percebe-se, também, a forma generalizada pelas quais as atribuições são aqui assentadas: uma ação supervisora impulsionada e ideologizada pela tônica técnico-fiscalizadora deveria legitimar as demais atividades (implícitas no texto legal) desenvolvidas pelo supervisor em nível escolar. Neste contexto, é reiterado o perfil profissional de agente de sistema na rede estadual, responsável pelo desenvolvimento educacional e respectivo padrão de qualidade. Todavia, a novidade (em relação aos dispositivos legais até aqui analisados) é trazida no inciso I do art. 9. ${ }^{\circ}$ : "[...] prestando a necessária orientação técnica e providenciando a correção de falhas administrativas e pedagógicas, sob pena de responsabilidade" (SÃO PAULO, 1993, p. 2 - grifos nossos). Neste art. fica expressamente oficializado que, em caso de descumprimento das referidas competências, o supervisor poderá ser avocado à responsabilidade mediante apuração de possíveis irregularidades pela autoridade competente. Nisso constata-se uma das características (neo)tecnicistas, intitulada pela "política de accountability", termo americano que designa dimensões articuláveis entre avaliação, prestação de contas e responsabilização (AFONSO, 2012, p. 472). Nesta abordagem, "[...] os educadores são chamados não para discutir os fundamentos da educação e sim a prestar contas accountability de suas competências" (NOSELLA, 2010, p. 34). Assim, também a supervisão precisa adaptar-se e ajustar-se à sociedade capitalista.

Passa-se a verificar as competências arroladas na LC 744/1993, correlacionadas aos seguintes $\mathrm{TV}^{24}$ : 
Tratamos de assunto referente a Del. 3/91 e verificamos os casos de recursos de alunos não se registrando casos de representação necessária da Supervisão. Os casos existentes serão submetidos, inicialmente, aos Conselhos respectivos. (TV de 31/01/1994)

Conforme já determinado pela Secretaria da Educação, demos início, às 9 horas ao sorteio dos candidatos às vagas da 1. ${ }^{\mathrm{a}}$ série do ensino médio, [...] dado o excesso da demanda. O sorteio foi feito no Salão [...], quase cheio de interessados, e com a participação de mães de alunos da própria escola que já estavam, previamente, com a vaga garantida. Número de alunos sorteados: 484. Vagas: 219. O sorteio terminou próximo do meio-dia, quando ainda houve mais algum tempo de atendimento a alunos e pais interessados em esclarecimentos. Tudo transcorreu em ordem. (TV de $10 / 12 / 1994)$

Durante quase dois anos (de 28/12/1993 - data da publicação da LC 744/1993 - a 01/01/1995, data que começa a viger o decreto 39.902), reconhece-se, sem indícios de alterações ou notáveis mudanças, o posicionamento habitual da supervisão face ao cumprimento das medidas predeterminadas. Ao ler os excertos acima, percebe-se que há uma despersonalização aparente do sujeito político face às atuações cotidianas; esta leva o especialista a perseverar-se como autêntico executor das implantações preceptoras das instâncias administrativas, fundamentado por um senso singular e esparso.

Em 01/011995, o Governador do Estado de São Paulo, Mário Covas, auxiliado pela professora Teresa Roserley Neubauer da Silva, Secretária de Educação, sancionou o Decreto $\mathrm{n}^{\mathbf{0}}$ 39.902. Este alterou alguns dispositivos dos Decretos 7.510/76 e 17.329/81, reorganizou os órgãos regionais da Secretaria de Estado da Educação e expediu as atribuições correspondentes às autoridades nele previsto. A atuação dos supervisores de ensino, a partir do referido Decreto, ficou instituída mediante o art. 13, atrelada às atribuições d: supervisionar atividades pedagógicas e de orientação educacional; colaborar na difusão e implementação das normas pedagógicas emanadas dos órgãos superiores; avaliar os resultados do processo de ensino-aprendizagem; analisar dados e elaborar alternativas de solução para os problemas específicos de cada nível e modalidade de ensino; assegurar a retroinformação ao planejamento curricular; opinar quanto à necessidade e oportunidade de treinamento para os recursos humanos; dar pareceres, realizar estudos e desenvolver outras atividades relacionadas com a supervisão pedagógica e de orientação educacional (SÃO PAULO, 1995).

Em 09/05/2000, a Secretaria de Educação, junto com o Departamento de Suprimento Escolar (DSE), publicou a Resolução SE $n^{\circ} 53$, que dispôs sobre a administração e o controle de estoques do Sistema Centralizado de Merenda Escolar. Esta estabeleceu no $\S$ único do art 11 e art. 14, que cabe à supervisão de ensino a verificação do gerenciamento do Programa de Merenda nas suas visitas às escolas, solicitando apoio do DSE, e, ainda, garantir a integração do sistema estadual de educação em seus aspectos administrativos, observando o cumprimento das normas legais e das determinações dos órgãos superiores (SÃO PAULO, 2000, grifos nossos).

Serão as competências do Decreto no 39.902/1995 e as da Resolução SE 53/2000 que nortearão o fazer supervisivo até o ano de 2002, quando a Secretaria de Educação publicou o Comunicado SE de 30/07/2002, no qual dispõe sobre o Perfil do Supervisor de Ensino. Assim, nesta última etapa da presente investigação conclui-se o cotejamento entre as normas legais e as associações do fazer supervisivo visualizadas mediante os assentamentos. Para tanto, aprecia-se os TV registrados entre 01/01/1995 (publicação do Decreto 39.902) a 31/12/2000, período final da pesquisa. Assim, o Comunicado SE de 30/07/2002 não será analisado, por exceder a periodicidade da pesquisa. 
Seguidamente transcreve-se alguns fragmentos dos TV que incidiram consonantemente com as atribuições expressas no art. 13 do Decreto 39.902/1995 e nos art. 11 e 14 da Resolução SE 53/2000:

Verifiquei os casos de retenção de alunos em uma disciplina e das séries finais do ensino fundamental e médio, e também os recursos. (TV de 04/01/1995)

Tratamos de assuntos relativos às duas avaliações solicitadas pelos órgãos superiores, avaliação de desempenho da Escola e do Plano Diretor/94, dentro do projeto Escola Padrão. (TV de 25/05/1995, grifos nossos)

Confirmamos os horários [de trabalho] do pessoal da direção, dos coordenadores e das reuniões dos professores com as coordenações. (TV de 14/06/1995)

[...] estive hoje, no período noturno, na EEPSG A, com o objetivo de vistoriar as classes, para conferir o número de alunos matriculados e os frequentes. [...] O Diretor, que nos recebeu, está assoberbado de trabalho, com falta de funcionários, mas mesmo com esses problemas, a $U E^{25}$ está funcionando muito bem. (TV de 09/04/1996, grifos nossos)

Conversamos sobre os cuidados legais que precisam ser observados nas mais diferentes situações escolares, sejam administrativas ou pedagógicas. Um estudo periódico e conjunto de legislação faz-se necessário em razão da atual conjuntura democrática que cobra das repartições públicas, transparência e envolvimento com a comunidade e seus problemas. Há problemas que devem ser encaminhados aos órgãos pertinentes como Conselho Tutelar, a Polícia etc. (TV de 25/10/2000)

Veja-se que as atividades desenvolvidas e, por conseguinte, a atuação dos supervisores é consoante com as normas legais que lhe determina competências. Interessante destacar que a grande maioria dos TV termina com a expressão descritiva praticamente padronizada: "a escola funciona normalmente" ou "a escola encontra-se em ordem". Parece que esta faz parte de um desfecho/arremate do supervisor, muito mais endereçado para o superior imediato (Delegado/Dirigente de Ensino) do que para os agentes intraescolares. Justifica-se o respectivo realce porque chama atenção constatar que há ocasiões em que o supervisor menciona questões relacionadas a insatisfatórios índices de evasão e repetência, faltas de professores e ausência de alunos, sorteio para matrículas em que quase a metade dos inscritos em fase escolar não foi contemplada, dentre outras temáticas e, não obstante, o registro assim é concluído.

Infere-se, neste caso, que as expressões "normal" e "em ordem" se dão no sentido de que elucidam a ordem e a normalidade pelo viés das condições físicas do prédio escolar, ou seja, disciplinar, ordeiro, moderado; e este só pode se dar se os alunos estiverem dentro das salas de aulas. Supõe-se que tal posicionamento caracteriza-se mediante vestígios (ainda não ultrapassados) do antigo inspetor que fiscalizava a ordem e o cumprimento fiel das regras. $\mathrm{O}$ "normal" em outras acepções/concepções deveria ser todos os alunos com direito a vagas, todos efetivamente aprendendo, todos concluindo o ano letivo, professores bem remunerados e tantos outros direitos educacionais.

\section{Apontamentos conclusivos}

À guisa de conclusão, considera-se imprescindível fazer algumas observações que se evidenciaram, mediante a análise dos dispositivos legais e respectivas induções na atuação dos supervisores a partir dos registros por eles exarados nos TV: 
- os dispositivos legais, emanados dos centros administrativos (governos federal e estadual), se fizeram presentes ao longo da trajetória histórica da inspeção/supervisão;

- as regulamentações, instruções e roteiros expressos na letra da lei balizaram, de forma direta o comportamento e a atuação da supervisão, imprimindo-lhe estilo, valores, concepções e determinado tipo de desempenho profissional;

- ainda que os dispositivos dos textos legais vicejassem para a execução de atividades voltadas ao processo de ensino-aprendizagem (mesmo considerando a prevalência em atribuições de cunho administrativo), os registros demonstraram uma tendência histórica ao desempenho de ações de natureza tecnoburocráticas. Essa característica se deu e se dá pelo histórico padrão estrutural que definiu a composição dos organismos da administração pública, dentre eles, o sistema educacional;

- observou-se que desde o recorte inicial da pesquisa até o final perdurou uma consoante predisposição da classe supervisora em promover e endossar atividades e comportamentos específicos voltados à educação moral, cívica e nacionalista;

- ao cumprir e fazer cumprir as determinações legais, a própria supervisão simbolizou e personificou a aparência estatal, tornando-se o "patrão" visível e próximo;

- ratifica-se certa transferência e migração, pelo inspetor/supervisor, das particularidades do discurso nomotético para as relações estabelecidas nas instituições escolares, como também, na formalidade e elaboração dos registros dos TV;

- ao se autocondicionar ao prescrito legal, o inspetor/supervisor aderiu à mesma concepção/ideário dos respectivos mentores: o consenso e a idealização da realidade, de modo que tais preceitos deveriam ser aplicados e cumpridos prontamente, independentemente das contradições que a própria realidade educacional revelara.

Diante do exposto e das observações demonstradas no recorte específico da investigação, focadas na dissonância ou na ressonância e/ou, ainda, na (in)validação das normas legais diante da atuação da supervisão, há que se concluir que de 1960 a 2000, nas escolas pesquisadas da Diretoria de Ensino de Itapetininga houve notória repercussão dos ditames legais na ação supervisora. Não obstante, pode-se pressupor que o enquadramento das disposições legais na concepção-prática do serviço de supervisão tem perdurado até os dias atuais e, de alguma forma, (re)ciclando a historicidade desse profissional.

\section{Referências}

AFONSO, Almerindo Janela. Para uma conceitualização alternativa de accountability em educação. Educação e Sociedade, Campinas, v. 33, n. 119, p. 471-484, abr./jun. 2012. Disponível em: <http://www.scielo.br/pdf/es/v33n119/a08v33n119.pdf>. Acesso em: 06 out. 2014.

ANTUNES, Ricardo. Da pragmática da especialização fragmentada à pragmática da liofilização flexibilizada: as formas da educação no modo de produção capitalista. Germinal: Marxismo e educação em debate, Londrina, v. 1, n. 1, p. 25-33, jun. 2009a. Disponível em: <http://www.uel.br/revistas/uel/index.php/germinal/article/view/2640>. Acesso em: 14 abr. 2013.

O trabalho, sua nova morfologia e a era da precarização estrutural. Revista THEOMAI/THEOMAI Journal, Buenos Aires, n. 19, set. 2009b. Disponível em: <http://revista-theomai.unq.edu.ar/numero19/artantunes.pdf>. Acesso em: 14 abr. 2013.

ARANHA, Maria Lúcia de Arruda. História da educação. 2. ed. São Paulo: Moderna, 1996.

ARROYO, Miguel Gonzalez. A supervisão no sistema de ensino: a organicidade administrativopedagógica. Revista APASE, São Paulo, ano 7, n. 9, p. 8-10, mai. 2008. 
BRASIL. Conselho Federal de Educação. Parecer no 252/1969. Fixa os mínimos de conteúdo e direção a serem observados na organização do curso de Pedagogia, 1969b. (Documenta, n. 100).

BRASIL. Constituição (1988). Constituição da República Federativa do Brasil: promulgada em 5 de outubro de 1988. Brasília, 1998.

BRASIL. Presidência da República. Decreto no $\mathbf{n}^{\mathbf{1 9}} \mathbf{8 9 0}$, de 18 de abril de 1931. Dispõe sobre a organização do ensino secundário. Disponível em: <http://www.planalto.gov.br/ccivil_03/decreto/1930-1949/D19890.htm>. Acesso em: 20 abr. 2013 .

BRASIL. Presidência da República. Decreto-Lei no 1.190, de 4 de Abril de 1939. Dá organização à Faculdade Nacional de Filosofia. Disponível em: <http://www2.camara.leg.br/legin/fed/declei/1930-1939/decreto-lei-1190-4-abril-1939349241-publicacaooriginal-1-pe.html>. Acesso em: 20 abr. 2013.

BRASIL. Presidência da República. Lei $n^{0}$ 4024, de 20 de dezembro de 1961. Fixa as Diretrizes e Bases da Educação Nacional. São Paulo: SE/CENP.

BRASIL. Presidência da República. Lei $n^{\circ}$ 5692, de 11 de agosto de 1971. Fixa Diretrizes e Bases para o ensino de $1^{\circ}$ e $2^{\circ}$ graus, e dá outras providências. Disponível em: <http://www.planalto.gov.br/ccivil_03/leis/15692.htm>. Acesso em: 20 ago. 2013.

BRASIL. Presidência da República. Lei no 9394, de 20 de dezembro de 1996. Estabelece as Diretrizes e Bases da Educação Nacional. São Paulo: SE/CENP, 2006.

BRASIL. Senado Federal. Lei $n^{0}$ 5540, de 28 de novembro de 1968. Fixa normas de organização e funcionamento do ensino superior e sua articulação com a escola média, e dá outras providências. São Paulo: SE/CENP.

BUENO, Maria Sylvia Simões. Caminhos e perspectivas da supervisão de ensino em território paulista na virada do milênio. In: MACHADO, Lourdes Marcelino; MAIA, Graziela Zambão Abdian (Org.). Administração e supervisão escolar: questões para o novo milênio. São Paulo: Pioneira Thomson Learning, 2003.

CHAUÍ, Marilena de Souza. O que é ideologia? 44. ed. São Paulo: Brasiliense, 1997

FERINI, Rosângela Aparecida. Uma abordagem histórico-ideológica da legislação. Revista APASE, São Paulo, ano 7, n. 9, p. 28-32, mai. 2008.

FRIGOTTO, Gaudêncio. Educação contemporânea: disputa de concepções, práticas e caminhos. Revista APASE, São Paulo, ano 9, n. 11, p 59-64, maio 2010.

GHIRALDELLI Jr., Paulo. História da educação. São Paulo: Cortez, 1994.

MEDEIROS, Luciene; ROSA, Solange. Supervisão educacional: possibilidades e limites. São Paulo: Cortez, 1987.

NOSELLA, Paolo. A atual política para a educação do Estado de São Paulo e da União: a cultura do desempenho. Revista APASE, São Paulo, ano 9, n. 11, p. 29-38, maio 2010.

PAIVA, Edil Vasconcelos de; PAIXÃO, Léa Pinheiro. O PABAEE e a supervisão escolar. In: SILVA JUNIOR, Celestino Alves da; RANGEL, Mary (Org.). Nove olhares sobre a supervisão. 9. ed. Campinas: Papirus, 1997.

QUAGLIO, Paschoal. Administração, supervisão, organização e funcionamento da educação brasileira. In: MACHADO, Lourdes Marcelino; MAIA, Graziela Zambão Abdian (Org.). Administração e supervisão escolar: questões para o novo milênio. São Paulo: Pioneira Thomson Learning, 2003. p. 49-58. 
SÃO PAULO (Estado). Decreto 5586, de 05/02/1975. Dispõe sobre atribuições dos cargos funções do Quadro do Magistério. São Paulo: SE/CENP.

SÃO PAULO (Estado). Decreto 7510, de 29/01/1976. Reorganiza a Secretaria de Estado da Educação. São Paulo: SE/CENP.

SÃO PAULO (Estado). Decreto 17.329, de 14/07/1981. Define a estrutura e as atribuições de órgãos e as competências das autoridades da Secretaria de Estado da Educação, em relação ao Sistema de Administração de Pessoal. Disponível em: <http://www.al.sp.gov.br/norma/?id=62948>. Acesso em: 20 jul. 2013.

SÃO PAULO (Estado). Decreto 39.902, de 02/01/1995. Altera os decretos $n^{\circ} 7.510 / 1976$, e 17.329/1981, reorganiza os órgãos regionais e dá providências correlatas São Paulo: SE/CENP.

SÃO PAULO (Estado). Lei 114, de 13/11/1974. Institui o Estatuto do Magistério Público $1^{\circ} \mathrm{e}$ $2^{\circ}$ graus do Estado e dá providências correlatas. São Paulo: SE/CENP.

SÃO PAULO (Estado). Lei Complementar 201, de 09 de novembro de 1978b. Institui $2^{\circ}$ Estatuto do Magistério Público $1^{\circ}$ e $2^{\circ}$ graus do Estado. São Paulo: SE/CENP.

SÃO PAULO (Estado). Lei Complementar 444/85. Institui $3^{\circ}$ Estatuto do Magistério Público do Estado. São Paulo: SE/CENP.

SÃO PAULO (Estado). Lei Complementar 744, de 28/12/1993. Institui vantagens para os integrantes da classe de Supervisor de Ensino, do Quadro do Magistério, e dá outras providências. São Paulo: SE/CENP.

SÃO PAULO (Estado). Lei Complementar 836, de 30 de dezembro de 1997. Institui Plano de Carreira, vencimentos e salários para os Integrantes do Quadro do Magistério da Secretaria da Educação e dá providências correlatas. São Paulo: SE/CENP.

SÃO PAULO (Estado). Resolução SE 53, de 9 de maio de 2000. Dispõe sobre procedimentos relativos a administração e controle de estoques do Sistema Centralizado de Merenda Escolar. Disponível

em: <http://siau.edunet.sp.gov.br/ItemLise/arquivos/53_2000.htm?Time=06/09/2014\%2008:02:52 >. Acesso em: 20 jul. 2014.

SAVIANI, Dermeval. Escola e democracia: teorias da educação, curvatura da vara onze teses sobre educação e política. São Paulo: Cortez: Autores Associados, 1988.

História das ideias pedagógicas no Brasil. 3. ed. rev. Campinas: Autores Associados, 2011. (Coleção memória da educação).

A supervisão educacional em perspectiva histórica: da função à profissão pela mediação da idéia. In: FERREIRA, Naura Syria Carapeto et al. (Org.). Supervisão educacional para uma escola de qualidade. 5. ed. São Paulo: Cortez, 2008.

SILVA JUNIOR, Celestino Alves da. Supervisão da educação: do autoritarismo ingênuo à vontade coletiva. 2. ed. São Paulo: Loyola, 1986.

UCZAK, Lucia Hugo. Supervisão escolar: diferentes papéis ao longo da trajetória. In: FRANCISCO, Denise Arina; SCHNEIDER, Elaine Cristina Araújo (Org). Ações, reflexões e desafios na formação do pedagogo na contemporaneidade. Novo Hamburgo: Feevale, 2010. p. 38-55. Disponível em: <http://books.google.com.br/books/about/A\%C3\%A7\%C3\%B5es_reflex\%C3\%B5es_e_desafio s_na_forma\%C3\%A7.html?hl=pt-BR\&id=GyLY7xirsc8C >. Acesso em: 14 set. 2014. 


\section{Notas}

${ }^{1}$ Supervisora na Diretoria de Ensino de Itapetininga/SP com mestrado em Educação. Graduada em Pedagogia, especialista em Gestão Educacional e em Gestão da Rede Pública, integrante do GPTeFE.

${ }^{2}$ Graduado em Filosofia, com mestrado e doutorado em Educação, é Editor da Crítica Educativa, coordenador do Programa de Mestrado em Educação da UFSCar Campus Sorocaba, líder do GPTeFE - Grupo de Pesquisa Teorias e Fundamentos da Educação - e bolsista PQ-CNPq.

${ }^{3}$ Vale registrar que a partir de 1978, realizaram-se os Encontros Nacional de Supervisores Educacionais (ENSEs) como espaços de reflexão crítica acerca da configuração da ação supervisora frente à realidade educacional brasileira.

${ }^{4}$ Em 14/11/81 procedeu-se a fundação da APASE - Associação Paulista de Supervisores de Ensino; em 1986 a reformulação do Estatuto da APASE e o $1^{\circ}$ Encontro Estadual de Supervisores de Ensino promovido pela APASE.

${ }^{5}$ Lei 10.172 de 09/01/2001: aprova o Plano Nacional de Educação (PNE: 2001 - 2010). Por exceder a periodicidade de nossa pesquisa não a apontamos no interior do quadro.

${ }^{6}$ De acordo com Aranha (1996) "[...] o populismo surge com a emergência das classes populares urbanas, resultantes da industrialização, insatisfeitas com suas condições de vida e trabalho. O governo populista revela-se ambíguo: se por um lado reconhece os anseios populares e reage sensivelmente às pressões, por outro, desenvolve uma "política de massa" procurando manipular e dirigir essas aspirações" (ARANHA, 1996, p.195).

${ }^{7}$ Para Ghiraldelli (1994, p. 119), o discurso do processo desenvolvimentista veiculava-se mediante a atração de interesses em diversos setores da economia. Os ideólogos prometiam a concretização das aspirações de ascensão social, garantidas pela crescente industrialização, sendo esta a solução irrevogável para a prosperidade nacional.

${ }^{8}$ Utiliza-se o termo "ideologia" e suas variações no decorrer deste artigo a partir do posicionamento de Chaú (1997). Para ela, a ideologia "[...] é um fato social justamente porque é produzida pelas relações sociais, possui razões muito determinadas para surgir e se conservar, não sendo um amontoado de idéias [...], mas uma certa maneira da produção das idéias pela sociedade, ou melhor, por formas históricas determinadas das relações sociais" (CHAUÍ, 1997, p. 31); "[...] nasce para servir aos interesses de uma classe e que só pode fazê-lo transformando as idéias dessa classe particular em idéias universais" (CHAUI, 1997, p. 97). Chaui também afirma que o Estado é um dos meios ideológicos existentes, uma vez que "[...] é a preservação dos interesses particulares da classe que domina a sociedade" (Idem, ibidem, p. 70).

${ }^{9}$ As trinta atribuições delimitadas nos campos "Curricular-Administrativo" serão arroladas por ocasião do Quadro 1 deste artigo.

${ }^{10}$ Periodicidade dos excertos: da LDB de 4.024, de 20/12/1961 à LC 114, de 13/11/1974 (registros de ordem técnica).

${ }^{11}$ Periodicidade dos excertos: da LDB de 4.024, de 20/12/1961 à LC 114, de 13/11/1974 (registros de ordem pedagógica).

${ }^{12}$ A duração do programa foi de 1957 a 1965 . A partir de 1965 o PABAEE transformou-se em Divisão de Aperfeiçoamento do Centro Regional de Pesquisas Educacionais João Pinheiro (DAP).

${ }^{13}$ Enquanto o PABAEE focava ações educacionais voltadas ao ensino elementar, a CADES - Campanha de Aperfeiçoamento e Difusão do Ensino Secundário - visava à elevação do nível secundário. Esta campanha, assinada pelo Presidente Getúlio Vargas - Decreto n 34.638, de 17/11/1953 -, perdurou de 1953 a 1968.

${ }^{14}$ CADES - Campanha de Aperfeiçoamento e Difusão do Ensino Secundário.

${ }^{15}$ Periodicidade dos excertos: TVs de 05/02/1975: publicação do Decreto 5.586 a 29/01/1976: publicação do Decreto 7510 .

${ }^{16}$ Carminado: avermelhado; significa escrever com caneta vermelha a palavra AUSENTE na página do Livro Ponto destinada a essa professora. 
${ }^{17}$ Em 09/11/1978, o governador do Estado de SP, Paulo Egydio Martins, assinou a LC no 201, intitulada por Estatuto do Magistério Público do Estado de SP. Neste a denominação "Supervisor Pedagógico" passa para "Supervisor de Ensino", mas não há explicitação de novas atribuições nesta LC. Desse modo, infere-se que as atribuições expressas no Decreto $\mathrm{n}^{\circ} 7510 / 1976$ ficaram vigentes, tendo em vista que ao final do texto da referida LC, na lista de leis que foram revogadas, não há menção ao Decreto 7510/1976. Justifica-se, assim, o cotejamento das atribuições e constatações nos TV de periodicidade entre 29/01/1976 a 28/12/1993, sendo que é nesta última data que entra em vigor a LC no 744/1993, reelaborando as atribuições do Supervisor de Ensino.

${ }^{18}$ CENP: Coordenadoria de Estudos e Normas Pedagógicas; órgão da Secretaria de Estado da Educação de São Paulo.

${ }^{19}$ CEFAM: Centro Específico de Formação e Aperfeiçoamento do Magistério, instalado em 1989 e extinto no final de 2005, pelo Secretário da Educação, Gabriel Benedito Issaac Chalita.

${ }^{20}$ Trata-se de uma visita inspecional da equipe central do Gabinete do Secretário de Estado da Educação de São Paulo. Os membros, procedentes da cidade de São Paulo, sede da SEESP, compareceram à unidade escolar para o cumprimento do art. 62 do Decreto $\mathrm{n}^{\circ} 7.510 / 76$, o qual determina um rol de atividades de natureza fiscalizatória.

${ }^{21}$ APM: Associação de Pais e Mestres.

${ }^{22}$ Nesta data, compareceu à escola uma equipe composta por oito (8) supervisores de ensino. Procederam à vistoria coletiva em diversos setores da unidade escolar.

${ }^{23}$ Considerando que a LC 201/78 não elenca novas atribuições à supervisão e o Decreto 17.329/1981 apenas suprime/altera algumas palavras que, no geral, não modificaram a atuação do supervisor, não serão apresentados novos excertos dos TVs, tendo em vista que as atribuições são as mesmas apresentadas pelo Decreto 7510/76 e, portanto, já arroladas e discutidas.

${ }^{24}$ Periodicidade dos excertos: TVs de 28/12/1993 (publicação da LC 744/1993) a 01/01/1995 (publicação do Decreto $\left.\mathrm{n}^{\circ} 39.902\right)$.

${ }^{25}$ UE: Unidade Escolar.

Recebido: abril-15 Aprovado: outubro-15 